\title{
Raccoon eye and Battle's sign in an infant with multiple Wormian bones
}

\author{
Yuji Fujita (1) ,' Shigeko Kuwashima, ${ }^{2}$ George Imataka, ${ }^{1}$ Shigemi Yoshihara ${ }^{1}$
}

Department of Pediatrics, Dokkyo Medical University, Shimotsuga, Tochigi, Japan ${ }^{2}$ Department of Radiology, Dokkyo Medical University, Shimotsuga, Tochigi, Japan

\section{Correspondence to} Dr Yuji Fujita; fujitay@dokkyomed.ac.jp

Accepted 8 June 2021
D) Check for updates

(c) BMJ Publishing Group Limited 2021. No commercial re-use. See rights and permissions. Published by BMJ.

To cite: Fujita Y,
Kuwashima S, Imataka G,
et al. BMJ Case Rep
2021;14:e241785.
doi:10.1136/bcr-2021-
241785

\section{DESCRIPTION}

An 8-month-old girl presented with a right raccoon eye and right Battle's sign (figure 1A,B), which are signs of a basal skull fracture, ${ }^{1}$ after a fall from a height of $40 \mathrm{~cm}$ the previous day. A head thin-slice CT scan revealed a right parietal bone simple fracture (figure 1C,D) and subcutaneous swelling. There was no cerebrospinal fluid leakage in her ears or nose, and no other signs of a basal skull fracture. The sensitivity of CT scan for diagnosing basal skull fractures is low, and as the specificity of raccoon eye and Battle's sign is extremely high, ${ }^{2}$ the patient was diagnosed with a basal skull fracture. The possibility of abuse was considered, but there were no other fractures, and no intraretinal bleeding on funduscopy. Follow-up MRI showed no leptomeningeal cyst.

Three-dimensional head CT revealed multiple Wormian bones (figure 1D). Wormian bones are considered normal variants, but if $>10$ Wormian bones are present, the presence of underlying diseases such as osteogenesis imperfecta should be considered. ${ }^{3-5}$ Our patient had a low lumbar bone density $(0.225 \mathrm{~g} /$ $\left.\mathrm{cm}^{2}\right) .{ }^{6}$ As she had $>10$ Wormian bones, we considered the possibility of her having an underlying condition associated with fracturability, but genetic testing did not reveal any mutations characteristic of osteogenesis
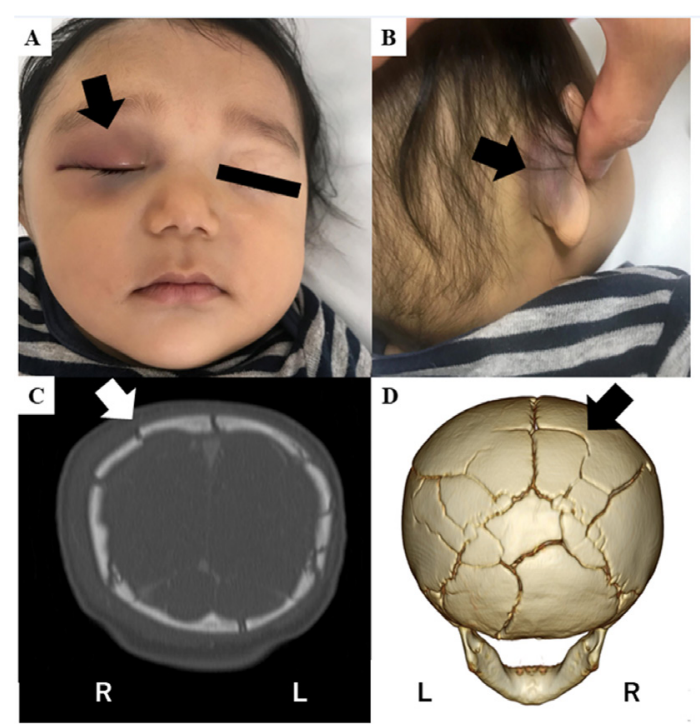

Figure 1 (A) Subcutaneous haemorrhage of the right eyelid indicating raccoon eye (black arrow). (B) Subcutaneous haemorrhage of the right posterior pinna indicating Battle's sign (black arrow). (C) Head CT scan revealed a right parietal bone fracture (black arrow) and subcutaneous haemorrhage (white arrow). (D) Head three-dimensional CT scan revealed a right parietal bone fracture (black arrow) and multiple Wormian bones.

\section{Patient's perspective}

We are glad that our daughter did not develop any nerve damage. We were worried that she would have another fracture due to minor injuries, but she has not had any fractures in the year since she was diagnosed with a skull fracture.

\section{Learning points}

- Paediatricians should consider a basal skul fracture in cases of raccoon eye and right Battle's sign.

- Paediatricians should look for signs, including cerebrospinal fluid leakage, in case of raccoon eye and Battle's sign.

- The presence of multiple Wormian bones may be a sign of an underlying brittle bone disease, such as osteogenesis imperfecta, which can result in repeated bone fractures following minor trauma.

imperfecta. No new fractures occurred during the year of follow-up.

Contributors YF drafted and revised the initial manuscript. SK, GI and SY critically revised the manuscript for important intellectual content. All authors read and approved the final manuscript.

Funding The authors have not declared a specific grant for this research from any funding agency in the public, commercial or not-for-profit sectors.

Competing interests None declared.

Patient consent for publication Parental/guardian consent obtained.

Provenance and peer review Not commissioned; externally peer reviewed.

\section{ORCID iD}

Yuji Fujita http://orcid.org/0000-0001-6440-9110

\section{REFERENCES}

1 Solai CA, Domingues CdeA, Nogueira LdeS, et al. Clinical signs of basilar skull fracture and their predictive value in diagnosis of this injury. J Trauma Nurs 2018;25:301-6

2 Olabinri EO, Ogbole Gl, Adeleye AO, et al. Comparative analysis of clinical and computed tomography features of basal skull fractures in head injury in southwestern Nigeria. J Neurosci Rural Pract 2015;6:139-44.

3 Cremin B, Goodman H, Spranger J, et al. Wormian bones in osteogenesis imperfecta and other disorders. Skeletal Radiol 1982;8:35-8

4 Sanchez-Lara PA, Graham JM, Hing AV, et al. The morphogenesis of wormian bones: a study of craniosynostosis and purposeful cranial deformation. Am J Med Genet A 2007;143A:3243-51. 
Images in...

5 Idriz S, Patel JH, Ameli Renani S, et al. CT of normal developmental and variant anatomy of the pediatric skull: distinguishing trauma from normality. Radiographics 2015;35:1585-601.
6 Manousaki D, Rauch F, Chabot G, et al. Pediatric data for dual X-ray absorptiometric measures of normal lumbar bone mineral density in children under 5 years of age using the lunar prodigy densitometer. J Musculoskelet Neuronal Interact 2016;16:247-55.

Copyright 2021 BMJ Publishing Group. All rights reserved. For permission to reuse any of this content visit

https://www.bmj.com/company/products-services/rights-and-licensing/permissions/

BMJ Case Report Fellows may re-use this article for personal use and teaching without any further permission.

Become a Fellow of BMJ Case Reports today and you can:

- Submit as many cases as you like

Enjoy fast sympathetic peer review and rapid publication of accepted articles

- Access all the published articles

Re-use any of the published material for personal use and teaching without further permission

Customer Service

If you have any further queries about your subscription, please contact our customer services team on +44 (0) 2071111105 or via email at support@bmj.com.

Visit casereports.bmj.com for more articles like this and to become a Fellow 